American Medical Journal 1 (1): 51-58, 2010

ISSN 1949-0070

(C) 2010 Science Publications

\title{
Physiological Study on the Effect of Acalypha wilkesiana Leaves Extract on Streptozotocin-Induced Experimental Diabetes in Male Mice
}

\author{
Atef M. Al-Attar \\ Department of Biological Sciences, Faculty of Sciences, King Abdul Aziz University, \\ P.O. Box 139109, Jeddah 21323, Saudi Arabia
}

\begin{abstract}
Problem statement: Diabetes mellitus is a chronic disease that causes serious health complications and it is now one of the most common non-communicable diseases globally. It is the fourth or fifth leading cause of death in most high-income countries and there is substantial evidence that it is epidemic in many economically developing and newly industrialized nations. Recently, there has been a growing interest in antidiabetic agents from natural products especially those derived from plants. The antidiabetic agents have been focused on plants used in traditional medicine because that may be a better treatment than currently used synthetic drugs. Approach: The influence of Acalypha wilkesiana leaves extract on the levels of serum glucose, triglycerides, cholesterol, sodium $(\mathrm{Na})$, potassium $(\mathrm{K})$ and Calcium $(\mathrm{Ca})$ was investigated using Streptozotocin (STZ)-induced diabetic mice. Diabetes was induced in male albino mice by single intraperitoneal injection of STZ (60 mg kg-1 body weight). The experimental animals were divided into four groups. The first group was untreated and served as normal control. The mice of second group were used as diabetic control group. The diabetic mice of third group were treated orally with $A$. wilkesiana leaves extract for 30 days. The normal mice of fourth group were treated orally with $A$. wilkesiana leaves extract at the same dose given to third group. Results: The diabetic mice showed significant increases in the levels of serum glucose, triglycerides, cholesterol and $\mathrm{Na}$ after 10, 20 and 30 days. Also, the level of $\mathrm{K}$ was statistically increased after 20 and 30 days, while the level of $\mathrm{Ca}$ was significantly elevated after 30 days. The diabetic mice given A. wilkesiana leaves extract showed significant decreases in the levels of serum glucose, cholesterol and K. Insignificant alterations in the values of serum triglycerides, $\mathrm{Na}$ and $\mathrm{Ca}$ were noted in diabetic mice treated with leaves extract at all periods of experiment. Conclusion/Recommendations: These new data indicate that $A$. wilkesiana represents an effective antihyperglycemic, antihyperlipidemic adjunct and ameliorative role on electrolytes disturbances for the treatment of diabetes and a potential source of discovery of new therapeutic agent.
\end{abstract}

Key words: Streptozotocin, diabetes, Acalypha wilkesiana, serum parameters, mice

\section{INTRODUCTION}

Glucose is the major energy source of cells. A stable blood glucose is necessary since energy must be supplied to all cells at all times despite intermittent food intake and variable demands, such as the level of physical activity. The major regulatory hormone for intermediary metabolism is insulin, produced and secreted by the $\beta$-cells of the islets of Langerhans of the pancreas. Impaired control of blood glucose concentrations by insulin leads to diabetes mellitus. In patients with diabetes, an increased blood glucose concentration (hyperglycemia) causes an increased thirst, hunger and urine volume, but it is the chronic complications of diabetes that are the major health issues (Partanen et al., 1995; Butler et al., 1998; Marks and Raskin, 2000; Torffvit and Agardh, 2000; 2001;
Voutilainen-Kaunisto et al., 2001). Diabetes is a major worldwide health problem predisposing to markedly increased cardiovascular mortality and serious morbidity and mortality related to the development of nephropathy, neuropathy and retinopathy. Diabetes mellitus is characterized by abnormal insulin secretion, derangement in carbohydrate and lipid metabolism and is diagnosed by presence of hyperglycemia (Zimmet et al., 1997). For many patients, diabetes is only diagnosed and aggressively treated when one of characteristic diabetic complications develops. These include cataracts and retinopathy which lead to blindness, impaired kidney function leading to endstage renal disease, diabetic neuropathy which may lead to tactile allodynia, ulcers or amputations, macro vascular disease such as atherosclerosis and impotence, or heart disease and stroke. In humans, diabetes is 
associated with long-term cardiovascular damage (especially endothelial dysfunction, fibrosis and cardiomyopathy) with a much higher risk of coronary artery disease, heart failure, myocardial infarction and death (Tomlinson et al., 1992). Diabetes can be induced by selective destruction of the insulin-producing $\beta$-cells of the pancreas with a single, rapid injection of Streptozotocin (STZ), a glucose moiety with a very reactive nitrosourea group from the mould Streptomyces griseus. This procedure, first introduced in 1963, has since been used in over 7600 PubMed citations, probably making this the second most used animal model of human disease after the Spontaneously Hypertensive Rat (SHR); cardiovascular changes following streptozotocin have been reviewed previously (Tomlinson et al., 1992). STZ doses of 50-65 $\mathrm{mg} \mathrm{kg}^{-1}$ lead to hyperglycemia (20-30 $\left.\mathrm{mmol} \mathrm{L}^{-1}\right)$ but severe ketosis does not develop even if insulin is not administered. Higher doses (75 $\mathrm{mg} \mathrm{kg}^{-1}$ and above) result in spontaneous ketosis and death within days if insulin is not given.

In modern medicine, there is no satisfactory effective therapy to cure diabetes mellitus. The management of diabetes mellitus by insulin therapy, has several drawbacks like insulin resistance (Wild et al., 2004) and in chronic treatment cause anorexia nervosa, brain atrophy and fatty liver (Tobias et al., 2001). Ethnobotanical information indicates that more than 800 plant are used as traditional remedies for the treatment of diabetes (Pushparaj et al., 2000), but many plants do not have a scientific scruting. Herbal medicines are used for primary health care, by about $80 \%$ of the world population particularly in the developing countries, because of better cultural acceptability, safety, efficacy, potent, inexpensive and lesser side effects (Pullaiah and Chandrasekhar Nadiu, 2003). The plant drugs are frequently considered to be less toxic when compared to synthetic drugs (Pari and Umamaheswari, 2000). More than 1123 plant species have been used to treat diabetes and more than 200 pure compounds have showed, lowering blood glucose activity (Grover et al., 2002). The WHO Expert Committee recommended that the important to investigate the hypoglycemic agents from plant origin, which used in traditional medicine for the treatment of diabetes mellitus (Alarcon-Aguilera et al., 1998). The antihyperglycemic agents have been focused on plants used in traditional medicine because that may be a better treatment than currently used synthetic drugs (Hu et al., 2003). Additionally, many plant extracts and plant products have been shown to have significant antioxidant activity (Anjali and Manoj, 1995) which may be an important property of plant medicines associated with the treatment of several ill fated diseases including diabetes. Thus, herbal plants are considered useful means to prevent and/or ameliorate certain disorders, such as diabetes, atherosclerosis and other complications (Scartezzini and Speroni, 2000).

Acalypha wilkesiana Muell Arg belongs to the family Euphorbiaceae (spurge family). Its other names include A. amentacea and A. tricolor, while its common names are copperleaf, Joseph's coat, fire dragon, match-me-if-you-can. It is native to Fiji and nearby islands in the South Pacificans is a popular outdoor plant that provides color throughout the year, although it is also grown indoors as a container plant. It is propagated by stem cuttings at any time of the year. Under ideal conditions, it grows as a spreading evergreen shrub with upright branches that tend to originate near the base and can get up to $3.1 \mathrm{~m}$ tall with a similar spread. It has leaves (12.7-20.3 cm long) that are alternate, elliptic to oval, serrate and multicoloredans small inconspicuous flowers $(10.2-20.3 \mathrm{~cm})$ that hangs in catkin-like racemes beneath the foliage. A. wilkesiana has antimicrobial (Ogundaini, 2005; Akinyemi et al., 2006; Oladunmoye, 2006) and antihypertension properties (Ikewuchi et al., 2008). According to Ogundaini (2005), the expressed juice or boiled decoction is used for the treatment of gastrointestinal disorders and fungal skin infections such as Pityriasis versicolar, Impetigo contagiosa, Candida intetrigo, Tinea versicolor, Tinea corporis and Tinea pedis. The objective of the present investigation was to ascertain the scientific basis for A. wilkesiana leaves extract use in the treatment of diabetes mellitus. Therefore, this study was designed to investigate the protective effect of $A$. wilkesiana leaves on lowering the levels of serum glucose, triglycerides and cholesterol levels and its ameliorative influences on serum sodium $(\mathrm{Na})$, potassium $(\mathrm{K})$ and Calcium $(\mathrm{Ca})$ disturbances in STZ-induced diabetic mice.

\section{MATERIALS AND METHODS}

Animals: The experiments were done using male albino mice of MF1 strain, weighing 27.2-33.8 g. The animals were maintained in controlled temperature $\left(20 \pm 1^{\circ} \mathrm{C}\right)$, humidity $(65 \%)$ and a $12 \mathrm{~h}$ dark-light cycle, with balanced food and free access to water. The protocol for these experiments was approved by the Committee on Experimental Animal Ethics of King Abdul Aziz University.

Preparation of leaves extract: Fresh young leaves of A. wilkesiana were directly collected from some botanical gardens in Cameron Highlands, Malaysia. 
The leaves were thoroughly washed and dried at room temperature. The fine quality of dried leaves was kept in dry plastic container until use for extract preparation. The aqueous extract of leaves was prepared every ten days. The dried leaves $(15 \mathrm{~g})$ were put in $500 \mathrm{~mL}$ cold water and mixed in an electric blender for $10 \mathrm{~min}$. The mixture was filtered and the resulting extract was stored in refrigerator for subsequent experiments.

Induction of diabetes: Experimental diabetes was induced in overnight fasted mice by intraperitoneal injection of STZ (Sigma-Aldrich Corp, St. Louis, MO, USA), $60 \mathrm{mg} \mathrm{kg}^{-1}$ body weight, dissolved in $0.9 \%$ $\mathrm{NaCl}$ solution. After 5 days, mice with glycemia above $17 \mathrm{mmol} \mathrm{L}^{-1}$ (at fasting state) were included in the study. Control mice were injected with saline solution.

Treatment: The treatment was started on the sixth day after STZ injection and this was considered as the first day of treatment. The treatment was continued for 30 days. The mice have been divided into four groups comprising 15 animals in each group as follows:

Group 1: Control mice given only saline solution

Group 2: Diabetic controls

Group 3: Diabetic mice treated orally with A. wilkesiana leaves extract ( $0.5 \mathrm{~mL} / \mathrm{mouse} /$ daily $)$

Group 4: Normal mice given saline solution and treated orally with $A$. wilkesiana leaves extract at the same dose given to group 3

Serum analysis: After 10, 20 and 30 days of treatment, food was withdrawn from the mice and they were fasted overnight but had free access to water. The experimental animals were anaesthetized with diethyl ether. Whole blood samples were collected from orbital venous plexus and emptied into plain tubes and allowed to clot. The clotted blood samples were thereafter centrifuged to recover serum from clotted cells. Serum was carefully separated and stored frozen until used for glucose, triglycerides, cholesterol, $\mathrm{Na}, \mathrm{K}$ and $\mathrm{Ca}$ determinations. Serum glucose, triglycerides and cholesterol were estimated using an automatic analyzer (Reflotron ${ }^{\circledR}$ Plus System, Roche, Germany). Serum Na, $\mathrm{K}$ and $\mathrm{Ca}$ were measured using Automated Clinical Chemistry Analysis System, Dimension ${ }^{\circledR}$ type RXL Max (Dade Behring Delaware, DE 19714, USA).

Statistical analysis: The data were expressed as mean \pm Standard Deviation (SD). Statistical comparisons were performed by one way Analysis Of Variance (ANOVA) followed by Duncans' Multiple Range Tests (DMRT). The results were considered statistically significant if the P-values were less than 0.05 .

\section{RESULTS}

Significant increases in the levels of serum glucose, triglycerides, cholesterol and $\mathrm{Na}$ were observed in diabetic rats when compared to control mice and STZ plus leaves extract or leaves extract treated mice after 10, 20 and 30 days (Fig. 1). The level of serum $\mathrm{K}$ was statistically decreased in diabetic mice (group 2) after 20 and 30 days compared with other groups. The level of serum $\mathrm{Ca}$ was significantly increased in group 2 after 30 days. Serum glucose value was statistically increased in diabetic mice treated with leaves extract at all periods compared with control and leaves extract treated mice (Fig. 1). The level of cholesterol was increased in STZ plus leaves extract treated mice after 10 days compared with group 4 and after 20 days compared with control and leaves extract treated mice. In comparison with leaves extract treated mice, the level of serum $\mathrm{K}$ was statistically decreased in group 3 after 30 days. Insignificant changes in the values of serum triglycerides, $\mathrm{Na}$ and $\mathrm{Ca}$ were observed in STZ plus leaves extract treated mice at all periods of experiment. Moreover, the levels of all studied parameters were statistically unchanged in mice treated with only leaves extract (Fig. 1). Table 1 shows the percentage changes of serum parameters values of all treated groups $(2,3$ ans 4$)$ compared with control mice (group 1). The maximum increases of serum glucose after $10(345.8 \%), 20(353.0 \%), 30(445.2 \%)$ days were observed in STZ-diabetic mice, while the treatment of diabetic mice with leaves extract (group 3) reduced the elevations of percentage change after 10 (303.9\%),

Table 1: Percentage changes of serum parameters values of STZ, STZ plus $A$. wilkesiana leaves extract and $A$. wilkesiana leaves extract treated mice after 10,20 and 30 days compared with control values

\begin{tabular}{llccc}
\hline & & \multicolumn{3}{c}{ Treatments } \\
& \multicolumn{3}{c}{ Time } & \multicolumn{3}{c}{$\begin{array}{l}\text { STZ+ leaves } \\
\text { Parameters }\end{array}$} & $\begin{array}{l}\text { Leaves } \\
\text { extract }\end{array}$ \\
\hline \multirow{3}{*}{ Glucose } & 10 & +345.8 & +303.9 & +0.23 \\
& 20 & +353.0 & +311.9 & -3.30 \\
Triglycerides & 30 & +445.2 & +305.6 & +0.70 \\
& 10 & +27.5 & +0.7 & -0.73 \\
& 20 & +33.1 & +1.5 & +0.73 \\
Cholesterol & 30 & +40.3 & -0.7 & -4.00 \\
& 10 & +29.6 & +4.7 & +0.47 \\
& 20 & +34.4 & 13.0 & +3.30 \\
Na & 30 & +57.1 & +8.1 & -2.90 \\
& 10 & +8.8 & +2.0 & +2.20 \\
& 20 & +10.8 & +1.0 & +0.13 \\
K & 30 & +16.2 & -0.3 & -3.50 \\
& 10 & -4.4 & +2.5 & +4.70 \\
& 20 & -9.2 & +1.8 & +3.10 \\
Ca & 30 & -11.9 & -2.4 & +3.90 \\
& 10 & -0.9 & +3.0 & -1.30 \\
& 20 & +5.3 & +3.1 & +2.20 \\
& 30 & +19.8 & +4.9 & +2.20 \\
\hline
\end{tabular}



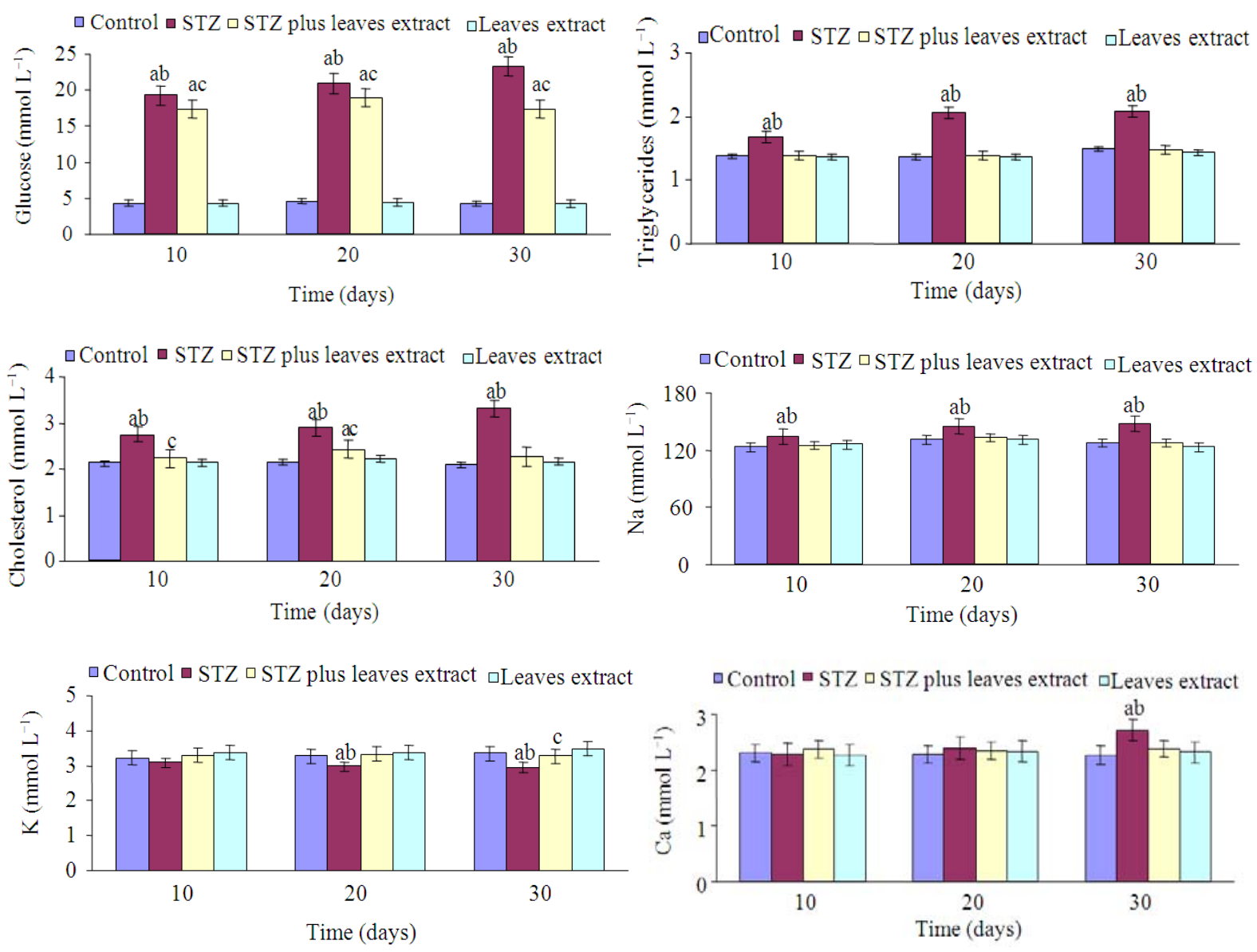

Fig. 1: Serum glucose, triglycerides, cholesterol, $\mathrm{Na}, \mathrm{K}$ and $\mathrm{Ca}$ values of control (group 1), STZ (group 2), STZ plus A. wilkesiana leaves extract (group 3) and A. wilkesiana leaves extract (group 4) treated mice after 10, 20 and 30 days $(n=6)$; (a) Indicates a significant difference between control and treated groups; (b) Indicates a significant difference between STZ treated group and groups treated with STZ plus A. wilkesiana leaves extract and A. wilkesiana leaves extract; (c) Indicates significant difference between STZ plus $A$. wilkesiana leaves extract treated group and group treated with only A. wilkesiana leaves extract

$20(311.9 \%)$ and $30(305.6 \%)$ days. The maximum increases of serum triglycerides $(40.3 \%)$, cholesterol (57.1\%), $\mathrm{Na}(16.2 \%)$ and $\mathrm{Ca}(19.8 \%)$ and the maximum decrease of $\mathrm{K}(11.9 \%)$ were noted in STZ-diabetic mice. From the present results, it is obviously that the percentage changes of serum parameters in group 2 were increased with the increases of experimental duration.

\section{DISCUSSION}

In the present study, the extract of A. wilkesiana leaves was investigated for antidiabetic activity on STZdiabetic mice. The levels of serum glucose, triglycerides and cholesterol were significantly higher in diabetic mice than in the control group. Similar observations were noted in different experimental diabetes investigations (Al-Attar and Zari. 2007; Geethan and Prince, 2008; Bang et al., 2009; Eliza et al., 2009; Roghani and Baluchnejadmojarad, 2010; Salahuddin et al., 2010). STZ produces hyperglycemia in a concentration dependent model by selective $\beta$-cells cytotoxic effect (Saini et al., 1996). The mechanism of action of STZ on rodent $\beta$-cells is related to uptake of STZ into $\beta$-cells and DNA strand breaks which then causes a lethal depletion of NAD, in $\beta$-cells (Swanston-Flatt et al., 1989; Saini et al., 1996). It has been shown that inhibition of free radical scavenger enzymes and enhancing production of the superoxide radical are the 
mechanism of STZ on pancreatic $\beta$-cells (SwanstonFlatt et al., 1989). From the present study, it is obviously that the administration of A. wilkesiana leaves extract to diabetic rats resulted in significant decline of serum glucose, cholesterol levels and protection of serum triglycerides level which statistically unchanged. The A. wilkesiana leaves extract might possess insulin like effect on peripheral tissues either by promoting glucose uptake and metabolism or inhibiting hepatic gluconeogenesis. A variety of derangements in metabolic and regulatory mechanisms, due to insulin deficiency, are responsible for the observed accumulation of lipids (Rajalingam et al., 1993). The impairment of insulin secretion results in enhanced metabolism of lipids from the adipose tissue to the plasma. Further, it has been reported that diabetic animals treated with insulin shows normalized lipid levels (Pathak et al., 1981). Thus, the results indicate that $A$. wilkesiana leaves shows insulin-like action by virtue of its lipid lowering levels.

Diabetes is characterized by increased volume and metabolites excretions via the kidneys, usually in excess of normal thresholds. These usually give rise to derangements in homeostatic balance with respect to electrolytes. It is well known that alterations in mineral metabolism can induce disturbance in glucose metabolism (Kumar et al., 1994; Rosolova et al., 1997; Paula et al., 1998) and glucose intolerance which also can interfere with mineral metabolism (de Lordes Lima et al., 1998). There is evidence that STZ-induced diabetes in experimental animals alters trace mineral balance as a result of disturbances in pancreatic function. In the present study, the levels of serum $\mathrm{Na}$ and $\mathrm{Ca}$ were statistically elevated in diabetic mice, while the level of serum $\mathrm{K}$ was significantly declined. In contrast, Shaheen et al. (2007) showed that the levels of serum $\mathrm{Na}$ and $\mathrm{Ca}$ were significantly decreased in STZ-induced diabetic rats, whereas serum $\mathrm{K}$ levels were increased non-significantly as compared to control rats. Atangwho et al. (2009) reported that the serum concentrations of $\mathrm{Na}$ and $\mathrm{K}$ of STZ-diabetic rats were decreased compared to the non-diabetic control. Ikpi et al. (2009) demonstrated that the level of serum $\mathrm{Na}$ was significantly decreased in alloxan-induced diabetic rats, while the level of $\mathrm{K}$ was statistically unchanged compared with control rats. Akah et al. (2009) showed that the level of serum $\mathrm{Na}$ was significantly unchanged in alloxan-induced diabetic rats, while the level of $\mathrm{K}$ was statistically increased compared with control rats. Gayathri and Kannabiran (2008) showed that in STZ-diabetic rats, there was a significant increase in the serum $\mathrm{Na}, \mathrm{K}$ and Ca. Uchiyama and Yamaguchi (2003) and Yamaguchi et al. (2007) demonstrated that the levels of serum $\mathrm{Ca}$ were increased in STZ-diabetic rats. Yanardag et al. (2005) and Ozsoy-Sacan et al. (2006) reported that in the STZ-diabetic rats, the blood Na and $\mathrm{K}$ levels were statistically increased.

Disorders of sodium and water balance are very common. Sodium is the principal solute in the extracellular compartment and hence the plasma osmolality largely depends on the serum sodium concentration. A decrease or increase in the serum sodium level will have an effect on the plasma osmolality and this can have deleterious effects on the whole body-in particular, the central nervous system. Severe hypo-and hypernatraemia are associated with significantly high mortality and morbidity. Moreover, inappropriate treatment may result in treatment related complications such as osmotic demyelination syndrome. Hypernatraemia is defined as serum or plasma sodium higher concentration. Hypernatraemia represents a deficit of water in relation to the body's sodium stores. It can result from net water loss or hypertonic sodium gain. Sustained hypernatraemia can occur only when thirst or access to water is impaired (Genanri, 1998). K homeostasis is essential for normal myocardial function. $\mathrm{K}$ plays a central role in the maintenance of cellular polarization and is critical for the transmission of electrical impulses through the myocardium. Alterations in the normal balance between intracellular and extracellular $\mathrm{K}$ concentrations can lead to serious arrhythmias (Grumbach et al., 1954; Ahmed et al., 2007). The adverse association between hypokalemia and arrhythmias in animal models appears to be more significant in the presence of acute myocardial ischemia (Grumbach et al., 1954; Yano et al., 1991). The major causes of low serum K are (1) decreased $\mathrm{K}$ intake due to intravenous feedings which do not contain $K$, (2) increased loss of $K$ in the urine due to accelerated tissue breakdown or renal lesions, (3) loss from the gastrointestinal tract due to diarrhea or fistulae and (4) shift between serum and cells due to metabolic causes, drugs or changes in $\mathrm{pH}$. Serum $\mathrm{Ca}$ is usually measured to screen for monitor diseases of the bone or calcium regulation disorders due to hormonal disturbance (parathormone and calctonin), vitamin D level and gastrointestinal absorption level of $\mathrm{Ca}$ and diseases of kidney. Yamaguchi et al. (2007) reported that the increase in serum $\mathrm{Ca}$ concentration in STZ-diabetic rats may result from the release of $\mathrm{Ca}$ from bone tissues; the femoral $\mathrm{Ca}$ content was found to decrease markedly in STZ-diabetic rats. Increased glucose oxidation in the presence of transition metals has been shown to produce membrane damage by 
membrane lipid peroxidation and protein glycation (Hunt et al., 1990). This could be the reason for the altered flux in electrolytes balance that resulted in the elevated extracellular concentration of $\mathrm{Na}$ and $\mathrm{Ca}$ in STZ-induced diabetic mice. Although the data obtained in this study do not allow any definite conclusions to be drawn on the mechanism of action of A. wilkesiana leaves extract on the levels of studied serum electrolytes in the experimental diabetic mice, it has been suggested that the active natural compounds of A. wilkesiana leaves might act by different pathways effect to cause the ameliorative activity.

\section{CONCLUSION}

Based on above mentioned observations, It can be concluded that this study shows for the first time that A. wilkesiana leaves extract supplementation is beneficial in lowering the level of blood glucose, improves the lipid and electrolytes profile in experimental diabetic mice. Further biochemical and pharmacological investigations will be required to study the influences of different concentrations and doses of A. wilkesiana leaves extract and its ingredients on STZ and other factors-induced diabetic animals.

\section{REFERENCES}

Ahmed, A., F. Zannad, T.E. Love, J. Tallaj and M. Gheorghiade et al., 2007. A propensitymatched study of the association of low serum potassium levels and mortality in chronic heart failure. Eur. Heart J., 28: 1334-1343. PMID: 17537738

Akah, P.A., J.A. Alemji, O.A. Salawu, T.C. Okoye and N.V. Offiah, 2009. Effects of Vernonia amygdalina on biochemical and hematological parameters in diabetic rats. Asian J. Med. Sci., 1: 108-113. maxwellsci.com/print/ajms/108-113.pdf

Akinyemi, K.O., O.K. Oluwaans and E.O. Omomigbehin, 2006. Antimicrobial activity of crude extracts of three medicinal plants used in south-western Nigerian folk medicine on some food borne bacterial pathogens. Afr. J. Trad. CAM., $\quad 3$ : 13-22. ajol.info/index.php/ajtcam/article/view/31173

Alarcon-Aguilera, F.J., R. Roman-Ramos and S. Perez-Gutierrez, 1998. Study of the antihyperglycemic effect of plants used as antidiabetics. J. Ethnopharmacol., 61: 101-110. PMID: 9683340

Al-Attar, A.M. and T.A. Zari, 2007. Modulatory effects of ginger and clove oils on physiological responses in streptozotocin-induced diabetic rats. Int. J. Pharmacol., 3: 34-40. DOI: 10.3923/ijp.2007.34.40
Anjali, P. and K.M. Manoj, 1995. Some comments on diabetes and herbal therapy. Ancient Sci. Life, 15: 27-29. ajol.info/index.php/tipr/article/view/14639/2744

Atangwho, I.J., E. Patrick, P.E. Ebong, E. Godwin and G.E. Egbung et al., 2009. Effects of coadministration of extracts of Vernonia amygdalina and Azadirachta indica on serum electrolyte profile of diabetic and non diabetic rats. Aust. J. Basic Appl. $\quad$ Sci., $\quad 3: \quad 2974-2978$. http://www.insipub.com/ajbas/2009/2974-2978.pdf

Bang, M.A., H.A. Kim and Y.J. Cho, 2009. Alterations in the blood glucose, serum lipids and renal oxidative stress in diabetic rats by supplementation of onion (Allium cepa. Linn). Nutr. Res. Pract., 3: 242-246. PMID: 20090891

Butler, R., T.M. Macdonald, A.D. Struthers and A.D. Morris, 1998. The clinical implications of diabetic heart disease. Eur. Heart J., 19: 1617-1627. PMID: 9857913

de Lordes Lima, M., L.E. Rodrigues, T. Cruz, K. Barbosa and C.P. Pousada et al., 1998. The effect of magnesium supplementation in increasing doses on the control of type 2 diabetes. Diabetes Care, 21: 682-686. PMID: 9589224

Eliza, J., P. Daisy, S. Ignacimuthu and V. Duraipandiyan, 2009. Antidiabetic and antilipidemic effect of eremanthin from Costus speciosus (Koen.) Sm., in STZ-induced diabetic rats. Chem. Biol. Interact., 182: 67-72. PMID: 19695236

Gayathri, M. and K. Kannabiran, 2008. Hypoglycemic activity of Hemidesmus indicus R. Br. on streptozotocin-induced diabetic rats. Int. J. Diabetes, 28: 6-10. PMID: 19902032

Geethan, P.K. and P.S. Prince, 2008. Antihyperlipidemic effect of D-pinitol on streptozotocin-induced diabetic Wistar rats. J. Biochem. Mol. Toxicol., 22: 220-224. PMID: 18752266

Genanri, F.J., 1998. Hypo-hypernatraemia: Disorders of water balance. In: Oxford Textbook of Clinical Nephrology, Davison, A.M., J.S. Cameron, J.P. Grunfeld, D.N.S. Kerr, E. Ritz and C.G. Winearls (Eds.), 2nd Edn., Vol. 1, Oxford, England, Oxford University, ISBN: 019262413X, pp: $175-200$.

Grover, J.K., S. Yadva and V. Vats, 2002. Medicinal plants of India with antidiabetic potential. J. Ethnopharmacol., 81: 81-100. PMID: 12020931

Grumbach, L., J.W. Howard and L.L. Merrill, 1954. Factors related to the irritation of ventricular fibrillation in the isolated heart: Effect of calcium and potassium. Circ. Res., 2: 452-459. www.springerlink.com/index/48Q76538250U3243. pdf 
Hu, X., J. Sato, Y. Oshida, M. Yu, G. Bajotto and Y. Sato, 2003. Effect of Gosha-jinki-gan (Chinese herbal medicine: Niu-sen-qi-wan) on insulin resistance on streptozotocin induced diabetic rats. Diabetes Res. Clin. Pract., 59: 103-111. PMID: 12560159

Hunt, J.V., C.C.T. Smith and S.P. Wolff, 1990. Autooxidative glycosylation and possible involvement of peroxides and free radicals in LDL modification by glucose. Diabetes, 9: 1420-1424. PMID: 2227114

Ikewuchi, J.C., A. Anyadiegwu, E.Y. Ugono and S.O. Okungbowa, 2008. Effect of Acalypha wilkesiana Muell. Arg. on plasma sodium and potassium concentration of normal rabbits. Pak. J. Nutr., 7: 130-132. DOI: 10.3923/pjn.2008.130.132

Ikpi, D.E., A.O. Obembe and C.O. Nku, 2009. Aqueous leaf extract of Rothmannia longiflora improves basal metabolic rate and electrolyte parameters in alloxan induced diabetic rats. Nigerian J. Physiol. Sci., 24: 67-71. PMID: 19826467

Kumar, S., A.O. Olukoga, C. Gordon, E.B. Mawer and M. France et al., 1994. Impaired glucose tolerance and insulin sensitivity in primary hyperparathyroidism. Clin. Endocrinol., 40: 47-53. PMID: 8306480

Marks, J.B. and P. Raskin, 2000. Cardiovascular risk in diabetes. A brief review. J. Diab. Complicat., 14: 108-115. PMID: 10959073

Ogundaini, A.O., 2005. From Greens Into Medicine: Taking a Lead From Nature. An Inaugural Lecture Delivered at Oduduwa Hall, Obafemi Awolowo University, Ile-Ife, Nigeria. Inaugural Lecture Series 176, OAU Press Limited, Ile-Ife, Nigeria, pp: 12-15.

http://www.akamaiuniversity.us/PJST10_2_829.pdf

Oladunmoye, M.K., 2006. Comparative evaluation of antimicrobial activities and phytochemical screening of two varieties of Acalypha wilkesiana. Int. J. Trop. Med., 1: 134-136. http://www.cababstractsplus.org/abstracts/Abstract. aspx?AcNo=20073213450

Ozsoy-Sacan, O., R. Yanardag, H. Orak, Y. Ozgey and A. Yarat et al., 2006. Effects of parsley (Petroselinum crispum) extract versus glibomuride on the liver of streptozotocin-induced diabetic rats. J. Ethnopharmacol., 104: 175-181. PMID: 16223573

Pari, L. and J. Umamaheswari, 2000. Antihyperglycemic activity of Musa sapientum flowers: Effect on lipid peroxidation in alloxan diabetic rats. Phytother. Res., 14: 136-138. PMID: 10685115
Partanen, J., L. Niskanen, J. Lehtinen, E. Mervaala and O. Siitonen et al., 1995. Natural history of peripheral neuropathy in patients with non-insulindependent diabetes mellitus. N. Engl. J. Med., 333: 89-94. PMID: 7777034

Pathak, R.M., S. Ansari and A. Mahmood, 1981. Changes in chemical composition of intestinal brush border membrane in alloxan induced chronic diabetes. Indian J. Exp. Biol., 19: 503-505. PMID: 7275211

Paula, F.J.A., A.E.C.M. Plens and C. Foss, 1998. Effects of hypophosphatemia on glucose tolerance and insulin secretion. Horm. Metab. Res., 30: 281-284. PMID: 9660090

Pullaiah, T. and K. Chandrasekhar Nadiu, 2003. Ant Diabetic Plants in India and Herbal Based Antidiabetic Research. Regency Publications, New Delhi, ISBN: 8187498676, pp: 3-9.

Pushparaj, P., C.H. Tan and B.K. Tan, 2000. Effects of Averrhoa bilimbi leaf extract on blood glucose and lipids in streptozotocin-diabetic rats. J. Ethnopharmacol., 72: 69-76. PMID: 10967456

Rajalingam, R., N. Srinivasan and P. Govindarajulu, 1993. Effect of alloxan induced diabetes on lipid profiles in renal cortex and medulla of mature albino rats. Indian J. Exp. Biol., 31: 577-579. PMID: 8406610

Roghani, M. and T. Baluchnejadmojarad, 2010. Hypoglycemic and hypolipidemic effect and antioxidant activity of chronic epigallocatechingallate in streptozotocin-diabetic rats. Pathophysiology, 17: 55-59. PMID: 19682872

Rosolova, H., O. Mayer and G. Reaven, 1997. Effect of variation in plasma magnesium concentration on resistance to insulin-mediated glucose disposal in nondiabetic subjects. J. Clin. Endocrinol. Metab., 82: 3783-3785. PMID: 9360541

Saini, K.S., C. Thompson, C.M. Winterford, N.I. Walker and D.P. Cameron, 1996. Streptozotocin at low doses induces apoptosis and at high doses causes necrosis in a murine pancreatic beta cell line. INS-1. Biochem. Mol. Biol. Int., 39: 1229-1236. PMID: 8876977

Salahuddin, M., S.S. Jalalpure and N.B. Gadge, 2010. Antidiabetic activity of aqueous bark extract of Cassia glauca in streptozotocin-induced diabetic rats. Can. J. Physiol. Pharmacol., 88: 153-160. PMID: 20237590

Scartezzini, P. and E. Speroni, 2000. Review on some plants of Indian traditional medicine with antioxidant activity. J. Ethnopharmacol., 71: 23-43. PMID: 10904144 
Shaheen, N., S. Muhammad and T. Mahboob, 2007. Effects of diltiazem on electrolytes homeostasis in streptozotocin-induced diabetic rats. Int. J. Pharmacol., $\quad 3: \quad 319-326 . \quad$ DOI: 10.3923/ijp.2007.319.326

Swanston-Flatt, S.K., C. Day, P.R. Flatt, B.J. Gould and C.J. Baily, 1989. Glycemic effects of traditional European plant treatment for diabetes. Studies in normal and streptozotocin diabetic mice. Diabetes Res., 10: 69-73. PMID: 2743711

Tobias, Y.J.A., A. Pinto and F. Neziroglu, 2001. Anorexia nervosa, diabetes mellitus, brain atrophyans fatty liver. Int. J. Eat Disord., 30: 350-353. PMID: 11746296

Tomlinson, K.C., S.M. Gardiner, R.A. Hebden and T. Bennett, 1992. Functional consequences of streptozotocin-induced diabetes mellitus, with particular reference to the cardiovascular system. Pharmacol. Rev., 44: 103-150. PMID: 1557425

Torffvit, O. and C.D. Agardh, 2000. The prognosis for type 2 diabetic patients with heart disease. A 10year observation study of 385 patients. J. Diab. Complicat., 14: 301-306. PMID: 11120453

Torffvit, O. and C.D. Agardh, 2001. The impact of metabolic and blood pressure control on incidence and progression of nephropathy. A 10-year study of 385 type 2 diabetic patients. J. Diab. Complicat., 15: 307-313. PMID: 11711324

Uchiyama, S. and M. Yamaguchi, 2003. Alteration in serum and bone component findings induced in streptozotocin-diabetic rats is restored by zinc acexamate. Int. J. Mol. Med., 12: 949-954. PMID: 14612972
Voutilainen-Kaunisto, R.M., M.E. Teravirta, M.I.J. Uusitupa and L.K. Niskanen, 2001. Occurrence and predictors of retinopathy and visual acuity in type 2 diabetic patients and control subjects 10-year follow-up from the diagnosis. J. Diab. Complicat., 15: 24-33. PMID: 11259923

Wild, S., G. Roglic, A. Green, R. Sicree and H. King, 2004. Global prevalence of diabetes. Diabetes Care, 27: 1047-1053. PMID: 15111519

Yamaguchi, M., R. Hamamoto, S. Uchiyama, K. Ishiyama and K. Hashimoto, 2007. Preventive effects of bee pollen Cistus ladaniferus extract on bone loss in streptozotocin-diabetic rats in vivo. J. Health Sci., 53: 190-195. jhs.pharm.or.jp/53(2)/53_190.pdf

Yanardag, R., O. Ozsoy-Sacan, S. Bolkent, H. Orak and O. Karabulut-Bulan, 2005. Protective effects of metformin treatment on the liver injury of streptozotocin-diabetic rats. Hum. Exp. Toxicol., 24: 129-135. PMID: 15901052

Yano, K., Y. Matsumoto and M. Hirata, 1991. Influence of sympathetic nerve activity on ventricular arrhythmogenicity in the dog with chronic hypokalemia. Angiology, 42: 878-888. PMID: 1952275

Zimmet, P.Z., D.J. McCartyans M.P. Courten, 1997. The global epidemiology of non-insulin dependent diabetes mellitus and the metabolic syndrome. J. Diab. Complicat., 11: 60-68. PMID: 9101389 